\title{
Kajian Peningkatan Produktivitas Padi Sawah Melalui Pengelolaan Hara Spesifik Lokasi (PHSL) Pada Lahan Berpotensi Hasil Rendah
}

\section{Study to increased lowland rice production through specific location of nutrient management (SLNM) on low potential productivity of lowland}

\section{Syahrial Abdullah}

Balai Pengkajian Teknologi Pertanian Sumatera Barat Jl. Raya Padang-Solok Km.40. Sukarami, Solok, Faks. 0755-31138

Email: syahrial.abd57@gmail.com

\begin{abstract}
The experiments was conducted at Kasang village, district of Batang Anai, Padang Pariaman regency during June until December 2013. The objectives of this experiment was to increased lowland rice production through specific location of nutrient management (SLNM) on low potential productivity of lowland. Four packages of fertilization such as Package $A, B, C$ and $D$ were arranged in Randomized Completely Block Design (RCBD) with 6 replications. Result of this experiment showed that; (1) SLNM treatments were significantly affected plant growth such as tiller number and plant high. Saveral of yield components also significantly affected by SLNM treatments packages such as panicles number, number of seeds per panicle, and percentage of filled grains. SLNM package A, B, and C significantly increased grain yields such as $24.9 \%$, 34.2\%, and $29.5 \%$ respectively compred to farmer package (Package D). The low grain yield with Famer package caused insufficient nutrient supplied for plant growth and yield is due to low fertilizer application and inaccurate nutrient management. The experiment suggested that the best application of inorganic fertilizer should be followed or combined with organic fertilizer such as animal manure or compost and the application of thus material should be in mature condition.
\end{abstract}

Key Words: rice, specific location, fertilizer

Diterima: 23 Oktober 2015, disetujui 24 Desember 2015

\section{PENDAHULUAN}

Menurut Abdurachman (2001) dalam upaya peningkatan produksi beras jangka panjang, ada tiga strategi yang mesti dilakukan, yaitu: (1) perluasan areal tanam dengan mencetak sawah baru, (2) peningkatan produktivitas dengan penerapan budi daya tanaman sesuai dengan konsep pengelolaan tanaman dan sumber daya terpadu (PTT) padi sawah, antara lain penggunaan varietas unggul baru (VUB) bermutu, penggunaan bibit umur muda, pengaturan sistem tanam, pengelolaan lahan dan air yang tepat, pemupukan lengkap yang rasional (pengelolaan hara yang tepat), pengendalian organisme 

pengganggu tanamam (OPT) sesuai dengan konsep pengendalian hama/penyakit terpadu (PHT), dan (3) perluasan areal panen melalui peningkatan indeks panen.

Dalam rangka mendukung program peningkatan produksi beras nasional (P2BN) maka peningkatan produksi padi perlu ditingkatkan, terutama untuk memenuhi kebutuhan pangan yang terus bertambah dari tahun ke tahun (Purwanto, 2008). Di sisi lain, tantangan yang dihadapi dalam pengadaan produksi padi tersebut semakin berat. Laju pertumbuhan penduduk dan tingkat konsumsi beras relatif tinggi mengharuskan peningkatan produksi yang berkelanjutan, sementara itu sebagian lahan sawah yang subur telah beralih fungsi untuk keperluan dan usaha lainnya.

Di Sumatera Barat produksi padi tahun 2012 tercatat sebesar 2.334.722 ton (atau mengalami peningkatan sebesar 2,53.\% dibanding tahun 2011 yang mencapai 2.267.358 ton. Peningkatan tersebut disebabkan oleh bertambahnya luas panen dan meningkatnya produktivitas tanaman atau hasil persatuan luas tanam (BPS Sumbar, 2012). Data rata-rata tingkat produktivitas padi sawah untuk masing-masing kabupaten/kota di Sumatera Barat menunjukkan keragaman yang cukup besar antar kecamatan. Keragaman rata-rata tingkat produktivitas padi sawah per kecamatan tersebut dipetakan dalam bentuk warna sebagai berikut; sangat rendah (merah: $<4,5 \mathrm{t} / \mathrm{ha}$ ); rendah (kuning: 4,5 $-5,0$ t/ha); sedang (hijau: 5,0 - 5,5 t/ha) dan tinggi (biru: > 5,5 t/ha) (Diperta Sumbar, 2012). Beberapa kecamatan masih memperlihatkan keragaan lahan dengan tingkat potensi hasil rendah, dan bahkan sangat rendah. Bila produksi padi sawah pada lokasi seperti itu dapat ditingkatkan dengan pengelolaan hara spesifik lokasi (PHSL), maka tingkat produksi padi di Sumatera Barat dapat ditingkatkan lebih tinggi lagi.

PHSL merupakan salah satu komponen teknologi dasar yang sangat dianjurkan untuk diterapkan dalam PTT padi sawah. Diharapkan melalui penerapan PHSL pada lahan dengan potensi hasil rendah akan mampu meningkatkan produksi padi sawah. Pengelolaan hara dilaksanakan melalui kegiatan pengelolaan pemupukan, baik pemberian pupuk anorganik maupun pupuk organik yang diaplikasikan berdasarkan pada status hara tanah dan kebutuhan tanaman (Kebutuhan pupuk P dan K tanaman ditentukan dengan menggunakan PUTS (Perangkat Uji Tanah Sawah), sedangkan kebutuhan $\mathrm{N}$ tanaman ditetapkan dengan mengukur tingkat kehijauan daun padi dengan menggunakan BWD (Bagan Warna Daun), dan pemberian bahan organik dalam bentuk pupuk kandang atau kompos.

PHSL dalam bentuk pengelolaan pemupukan merupakan salah satu faktor kunci untuk mendukung peningkatan produksi padi sawah. Pengaruh pemupukan terhadap produksi padi, baik peningkatan hasil maupun kualitas hasil telah banyak dikaji. Peneliti terdahulu melaporkan bahwa pemberian pupuk mineral (anorganik fertilizer) nyata meningkatkan produksi padi dengan tingkat respon/tanggap tanaman padi terhadap pemupukan yang beragam, yang dipengaruhi oleh tipe tanah sawah, varietas padi yang ditanam, iklim dan cuaca, cara bercocok tanam, jenis tanah dan potensi lahan sawah tersebut (Sukristiyonubowo 2007; Mandal et al. 2003; Cho et al, 2002; Adiningsih et al, 1989; dan Adiningsih, 1992). Produksi padi pada lahan dengan potensi hasil rendah biasanya bereaksi masam. Hal ini antara lain disebabkan oleh rendahnya efisiensi pemupukan, karena tingginya kehilangan hara akibat pelindian dan pencucian, serta keracunan besi (Sukristiyonubowo et al. 2009b; Anonim 2005).

PHSL merupakan suatu pendekatan untuk menyediakan hara bagi tanaman padi saat dan bila dibutuhkan. Aplikasi dan pengelolaan hara secara dinamis disesuaikan dengan kebutuhan tanaman menurut lokasi dan musim tanam. Pemberian pupuk yang tepat takaran, tepat waktu dan jenis pupuk yang diberikan sesuai maka pemupukan akan lebih efisien dan hasil tinggi (Widowati dan Rochayati 2008). PHSL ditujukan untuk membantu petani padi meningkatkan hasil panen dan pendapatan mereka dengan menerapkan pemupukan dalam jumlah dan waktu yang tepat. 
Pengkajian bertujuan untuk meningkatkan produksi padi sawah melalui pengelolaan hara spesifik lokasi (PHSL) pada lahan dengan potensi hasil rendah di Sumatera Barat.

\section{METODE}

Penelitian dilaksanakan di lahan sawah petani dengan tingkat potensi hasil rendah di Nagari Kasang, Kecamatan Batang Anai, Kabupaten Padang Pariaman Penetapan lokasi penelitian berdasarkan pada tingkat produktivitas lahan sawah per kecamatan dari Provinsi Sumatera Barat (Diperta Sumbar, 2012), kemudian dilakukan koodinasi dengan Dinas Pertanian Tanaman Pangan Kabupaten Padang Pariaman. Waktu penelitian dilaksanakan pada bulan Juni - Desember 2013.

Alat yang digunakan pada kegiatan pengkajian ini antara lain adalah; Perangkat Uji Tanah Sawah (PUTS), bagan warna daun (BWD), meteran, timbangan, sabit, cangkul, parang dan alat tulis kantor (ATK). Sedangkan bahan yang digunakan adalah; benih padi sawah varietas Inpari 21 Batipuah, pupuk Urea, pupuk SP36, pupuk KCl, pupuk majemuk Phonska, pupuk kandang (Pukan), kompos jerami, Insektisida Karbofuran (Curater 3G), Ripcord, dan fungisida Fujiwan, serta bahan habis pakai lainnya seperti kantong kertas, karung plastik, dan spidol.

Perlaksanaan penelitian dengan memperlakuan pengelolaan hara spesifik lokasi (PHSL) dalam bentuk paket pemupukan adalah sebagai berikut (Tabel 1).

Tabel 1. Perlakuan pengelolaan hara spesifik lokasi (PHSL), TA. 2013

\begin{tabular}{|c|c|c|}
\hline \multirow[t]{2}{*}{ Perlakuan } & \multicolumn{2}{|r|}{ Uraian } \\
\hline & PHSL & Takaran Pupuk \& Cara Aplikasi \\
\hline Paket A & $\begin{array}{l}\text {-P dan K berdasarkan } \\
\text { PUTS -Pemupukan N- } \\
\text { BWD } \\
\text {-Tanpa bahan organik }\end{array}$ & $\begin{array}{l}125 \mathrm{~kg} / \mathrm{ha} \mathrm{SP} 36,100 \mathrm{~kg} / \mathrm{ha} \mathrm{KCl} \mathrm{dan} 200 \\
\mathrm{~kg} / \mathrm{ha} \mathrm{Urea.} \mathrm{Seluruh} \mathrm{SP36} \mathrm{+} 50 \mathrm{~kg} / \mathrm{ha} \mathrm{KCl} \\
+75 \mathrm{~kg} / \mathrm{ha} \text { Urea diberikan pada umur } 3 \\
\mathrm{HST} .50 \mathrm{~kg} / \mathrm{ha} \mathrm{KCl}+75 \mathrm{~kg} / \mathrm{ha} \text { Urea pada } \\
\text { umur } 30 \mathrm{HST} \text {, dan } 50 \mathrm{~kg} / \mathrm{ha} \text { Urea pada } \\
\text { saat IM (umur } 50 \mathrm{HST}\end{array}$ \\
\hline Paket B & $\begin{array}{l}\text {-P dan K berdasarkan } \\
\text { PUTS - Pemupukan N- } \\
\text { BWD } \\
\text {-Bahan organik Pukan }\end{array}$ & $\begin{array}{l}125 \mathrm{~kg} / \mathrm{ha} \mathrm{SP} 36,100 \mathrm{~kg} / \mathrm{ha} \mathrm{KCl} \text { dan } 200 \\
\mathrm{~kg} / \mathrm{ha} \text { Urea.Pukan }(5 \mathrm{t} / \mathrm{ha}) \mathrm{saat} \text { pengolahan } \\
\text { tanah terakhir. Seluruh SP36 + 50 kg/ha } \\
\mathrm{KCl}+75 \mathrm{~kg} / \mathrm{ha} \text { Urea diberikan pada umur } \\
3 \mathrm{HST} .50 \mathrm{~kg} / \mathrm{ha} \mathrm{KCl}+75 \mathrm{~kg} / \mathrm{ha} \text { Urea } \\
\text { pada umur } 30 \mathrm{HST} \text {, dan } 50 \mathrm{~kg} / \mathrm{ha} \text { Urea } \\
\text { pada saat IM (umur } 50 \mathrm{HST} \text { ) }\end{array}$ \\
\hline Paket C & $\begin{array}{l}\text {-P dan K berdasarkan } \\
\text { PUTS - Pemupukan N- } \\
\text { BWD } \\
\text {-Bahan organik Kompos } \\
\text { jerami }\end{array}$ & $\begin{array}{l}125 \mathrm{~kg} / \mathrm{ha} \mathrm{SP} 36,100 \mathrm{~kg} / \mathrm{ha} \mathrm{KCl} \text { dan } 200 \\
\mathrm{~kg} / \mathrm{ha} \text { Urea. Kompos }(5 \mathrm{t} / \mathrm{ha}) \text { saat } \\
\text { pengolahan tanah terakhir.Seluruh SP36 + } \\
50 \mathrm{~kg} / \mathrm{ha} \mathrm{KCl}+75 \mathrm{~kg} / \mathrm{ha} \text { Urea diberikan } \\
\text { pada umur } 3 \mathrm{HST} .50 \mathrm{~kg} / \mathrm{ha} \mathrm{KCl}+75 \\
\mathrm{~kg} / \mathrm{ha} \text { Urea pada umur } 30 \mathrm{HST} \text {, dan } 50 \\
\mathrm{~kg} / \mathrm{ha} \text { Urea pada saat IM (umur } 50 \mathrm{HST} \text { ) }\end{array}$ \\
\hline Paket Patani & -Pemupukan Cara Petani & $\begin{array}{l}100 \mathrm{kgha} \text { pupuk Phonska dan } 150 \mathrm{~kg} / \mathrm{ha} \\
\text { Urea dicampur dan diaplikasi-kan } 2 \mathrm{kali} \text {, } \\
\text { masing-masing separohnya pada umur 10- } \\
15 \mathrm{HST} \text {, dan umur } 40 \mathrm{HST} \text {. }\end{array}$ \\
\hline
\end{tabular}


Unit perlakuan menggunakan lahan sawah petani, masing-masing dengan ukuran seluas lebih kurang 4 are dengan 6 kali ulangan, sehingga untuk 1 Paket perlakuan dibutuhkan lahan seluas lebih kurang 25 are. Dengan demikian untuk 4 paket perlakuan pada kegiatan ini dibutuhkan lahan sawah lebih kurang seluas 1,0 ha. Pengkajian lapang menggunakan rancangan acak kelompok (RAK). Sebagai tanaman indikator digunakan padi sawah varietas Inpari 21 Batipuh.

Pengambilan contoh tanah untuk analisis tanah diambil di lokasi pengkajian sebelum pelaksanaan kegiatan di lapangan (setelah panen tanaman petani sebelumnya). Tanaman contoh untuk pengamatan pertumbuhan tanaman, komponen hasil dan hasil diambil secara acak dan disesuaikan dengan kebutuhan analisis.

Pemupukan berdasarkan pada pengelolaan hara spesifik lokasi (PHSL), dimana untuk menentukan penggunan pupuk P (SP36) dan $\mathrm{K}(\mathrm{KCl})$ ditentukan dengan alat PUTS (Perangkat Uji Tanah Sawah). Sedangkan aplikasi pupuk N (urea) berdasarkan hasil pengamatan pada tanaman dengan menggunakan bagan warna daun (BWD) waktu tetap (fixed time). Acuan untuk pemupukan $\mathrm{P}$ dan K berdasarkan status hara tanah dapat di lihat pada Tabel 2 dan Tabel 3 (Balai Penelitian Tanah 2009).

Tabel 2. Takaran pemupukan P (SP36) berdasarkan status hara $\mathrm{P}$ tanah

\begin{tabular}{|c|c|c|}
\hline Status Hara P tanah & $\begin{array}{c}\text { Perkiraan } \\
\text { Kadar hara terekstrak } \\
\mathrm{HCl} 25 \%(\mathrm{mg} \mathrm{P} \mathrm{O} / 100 \mathrm{~g})\end{array}$ & $\begin{array}{c}\text { Takaran Pupuk SP36 } \\
(\mathrm{kg} / \mathrm{ha} / \mathrm{musim})\end{array}$ \\
\hline Rendah & $<20$ & 125 \\
\hline Sedang & $20-40$ & 75 \\
\hline Tinggi & $>40$ & 50 \\
\hline
\end{tabular}

Sumber: Balai Penelitian Tanah, 2009

Tabel 3. Takaran pemupukan $\mathrm{K}(\mathrm{KCl})$ berdasarkan status hara $\mathrm{K}$ tanah

\begin{tabular}{ccc}
\hline Status Hara K Tanah & $\begin{array}{c}\text { Perkiraan } \\
\text { Kadar hara terekstrak } \\
\mathrm{HCl} \mathrm{25 \%}(\mathrm{mg} \mathrm{K} 2 \mathrm{O} / 100 \mathrm{~g})\end{array}$ & $\begin{array}{c}\text { Takaran Pupuk KCl } \\
(\mathrm{kg} / \mathrm{ha} / \text { musim })\end{array}$ \\
\hline Rendah & $<10$ & 100 \\
Sedang & $10-20$ & 50 \\
Tinggi & $>20$ & 50 \\
\hline
\end{tabular}

Sumber: Balai Penelitian Tanah, 2009.

Pengendalian siangan (gulma) dilakukan secara manual sebanyak 2 kali, masing-masing pada umur 3 minggu setelah tanam (MST) dan 6 MST. Pada saat tanam, diaplikasikan insektisida Carbofuran sebanyak $17 \mathrm{~kg} / \mathrm{ha}$. Fungisida Fujiwan dengan takaran $2 \mathrm{ml} /$ liter air digunakan untuk mengendalikan penyakit blas, sedangkan hama walang sangit dikendalikan dengan insektisida Ripcord dengan takaran aplikasi sebanyak $2 \mathrm{ml} /$ liter air. Pemberian air dilakukan secara berselang, yaitu; (a) pada waktu tanam bibit pada kondisi tanah jenuh air, (b) 3-5 hari setelah tanam petakan sawah diairi dengan tinggi air sekitar $3 \mathrm{~cm}$, kemudian diairi lagi pada hari ke 5, cara pemberian air seperti ini berlangsung sampai stadia anakan maksimum, (c) sejak stadia pembentukan malai sampai pengisian biji petakan sawah diairi sekitar $3 \mathrm{~cm}$, dan (d) petakan sawah dikeringkan sekitar 10 hari sebelum panen. 
Pengamatan pada parameter penelitian sebagai berikut:

(1) Contoh tanah pada awal tanam diambil secara komposit, pengambilan contoh setelah pengolahan tanah selesai atau sebelum pemupukan. Pengambilan contoh tanah untuk keperluan analisis tanah dengan Perangkat Uji Tanah Sawah (PUTS). Penetapan takaran pemupukan berdasarkan pada hasil uji tanah dengan PUTS, dan pengamatan tanaman dengan BWD untuk aplikasi pupuk $\mathrm{N}$ susulan.

(2) Pengelolaan tanaman dan pengamatan keragaan pertumbuhan tanaman; Pertumbuhan tanaman meliputi: jumlah anakan dan tinggi tanaman diamati pada stadia anakan aktif, saat primordia dan saat panen. Pengukuran dilakukan pada 10 rumpun contoh yang sama pada setiap perlakuan.

(3) Pengambilan contoh tanaman untuk keperluan analisis komponen hasil, dan pengamatan tanaman pada stadia generatif; Data komponen hasil yaitu jumlah malai per rumpun, jumlah gabah per malai, persen gabah isi, dan bobot 1000 butir dapat diperoleh dengan cara mengambil 12 rumpun contoh (dipotong batangnya tepat di permukaan tanah) untuk setiap perlakuan pada saat matang fisiologis.

(4) Panen dan pengelolaan (prosesing) hasil panen pada saat tanaman telah siap dipanen; Data hasil panen di ambil dari setiap perlakuan dengan ukuran ubinan seluas $100 \mathrm{~m}^{2}$. Rontok gabah dari malainya, bersihkan dari kotoran dan timbang beratnya (B kg). Setelah gabah ditimbang beratnya, segera ukur kadar airnya (K.A). Konversikan hasilnya ke berat kering giling (K.A = $14 \%)$ dengan rumus sebagai berikut:

Hasil gabah kering giling per ubinan $(\mathrm{BU})=(100-\mathrm{KA}) / 86) \times \mathrm{B} \mathrm{kg}$

Hasil Gabah kering giling per hektar $=\left(10.000 \mathrm{~m}^{2} / 100 \mathrm{~m}^{2}\right) \times \mathrm{BU} \mathrm{kg}$

\section{HASIL DAN PEMBAHASAN}

Kajian peningkatan produksi padi sawah melalui pengelolaan hara spesifik lokasi (PHSL) pada lahan berpotensi hasil rendah telah dilaksanakan di Kelompok Tani "Saiyo Sakato" Nagari Kasang, Kecamatan Batang Anai, Kabupaten Padang Pariaman pada bulan Juni sampai Desember 2013. Hasil analisis tanah dengan PUTS menunjukkan bahwa status hara $\mathrm{P}$ dan $\mathrm{K}$ tanah tergolong rendah, sehingga takaran pemupukan P dan K berdasarkan PHSL masing-masing sebanyak $125 \mathrm{~kg} / \mathrm{ha} \mathrm{SP36}$, dan $100 \mathrm{~kg} / \mathrm{ha} \mathrm{KCl}$. Sedangkan total pemupukan Urea berdasakan bagan warna daun (BWD) adalah sebanyak $200 \mathrm{~kg} / \mathrm{ha}$ pupuk Urea. Berdasarkan survey di lokasi pengkajian takaran perlakuan pemupukan Paket Petani adalah $100 \mathrm{~kg} / \mathrm{ha}$ pupuk Phonska dan $100 \mathrm{~kg} / \mathrm{ha}$ Urea.

\section{Pertumbuhan Tanaman Padi Sawah}

Hasil rata-rata pengamatan pengaruh pengelolaan hara spesifik lokasi (PHSL) terhadap jumlah anakan dan tinggi tanaman pada umur 28 HST (stadia anakan produktif), umur 49 HST (stadia inisiasi malai), dan tinggi tanaman padi sawah varietas Inpari 21 Batipuah pada saat panen dapat dilihat pada Tabel 4.

Data rata-rata hasil pengamatan menunjukkan bahwa jumlah anakan padi umur 28 HST memberikan jumlah anakan terbanyak dengan perlakuan PHSL Paket C (313 anakan.m ${ }^{-2}$ ), kemudian dikuti oleh Paket B dan Paket A, dan jumlah anakan yang terendah (232 anakan. $\left.\mathrm{m}^{-2}\right)$ terlihat dengan Paket Petani. Sedangkan rata-rata hasil pengamatan tinggi tanaman pada umur 28 HST tersebut relatif tidak berbeda, dimana tinggi tanaman berkisar 31,7 - 37,1 cm. Pemberian bahan organik pada perlakuan B dan C baik dalam bentuk pupuk kandang (Pukan) atau kompos menunjukkan dampak 
Syahrial, A., dkk: Kajian Peningkatan Produktivitas Padi Sawah Melalui Pengelolaan Hara Spesifik .......

positif, hal ini diperlihatkan dengan keragaan pertumbuhan tanaman yang baik seperti jumlah anakan dan tinggi tanaman.

Tabel 4. Pengaruh perlakuan pengelolaan hara spesifik lokasi (PHSL) terhadap pertumbuhan padi sawah pada lahan berpotensi hasil rendah di Kasang, Kec. Batang Anai, Kabupaten Padang Pariaman MT. 2013.

\begin{tabular}{|c|c|c|c|c|c|}
\hline \multirow{3}{*}{$\begin{array}{l}\text { Perlakuan*) } \\
\text { PHSL }\end{array}$} & \multicolumn{5}{|c|}{ Pertumbuhaan tanaman umur } \\
\hline & \multicolumn{2}{|c|}{ Umur 28 HST } & \multicolumn{2}{|c|}{ Umur 49 HST } & \multirow{2}{*}{$\begin{array}{c}\text { Saat panen } \\
\begin{array}{c}\text { Tg.Tanaman } \\
(\mathrm{cm})\end{array}\end{array}$} \\
\hline & $\begin{array}{l}\text { Jml Anakan } \\
\left(\text { anakan.m }^{-2}\right)\end{array}$ & $\begin{array}{l}\text { Tg.Tanaman } \\
(\mathrm{cm})\end{array}$ & $\begin{array}{l}\text { Jml Anakan } \\
\left(\text { anakan.m }^{-2}\right)\end{array}$ & $\begin{array}{l}\text { Tg.Tanaman } \\
(\mathrm{cm})\end{array}$ & \\
\hline Paket A & $267 \mathrm{~b}$ & $35,1 \mathrm{a}$ & $362 \mathrm{ab}$ & $68,7 \mathrm{a}$ & $102,2 \mathrm{a}$ \\
\hline Paket B & $305 \mathrm{a}$ & $33,5 \mathrm{ab}$ & $393 \mathrm{a}$ & $67,1 \mathrm{a}$ & $101,9 \mathrm{a}$ \\
\hline Paket C & $313 \mathrm{a}$ & $34,7 \mathrm{a}$ & 389 a & $68,9 \mathrm{a}$ & $103,0 \mathrm{a}$ \\
\hline Paket Petani & $232 \mathrm{c}$ & $32,7 \mathrm{~b}$ & $318 \mathrm{~b}$ & $64,4 \mathrm{a}$ & $97,1 \mathrm{~b}$ \\
\hline
\end{tabular}

Angka selajur yang diikuti oleh huruf kecil yang sama tidak berbeda nyata menurut DNMRT 5\% ${ }^{*}$

Hasil pengamatan terhadap jumlah anakan maksimum, pada 49 HST (stadia inisiasi malai), didapatkan jumlah anakan terbanyak $\left(393\right.$ anakan. $\mathrm{m}^{-2}$ ) dengan Paket B, kemudian diikuti oleh Paket C dan Paket A, sedangkan jumlah anakan terendah (318 anakan. $\mathrm{m}^{-2}$ ) kembali terlihat dengan Paket Petani. Hasil pengamatan tinggi tanaman pada saat panen didapatkan bahwa tanaman tertinggi (103,0 $\mathrm{cm}$ ) terlihat dengan Paket C, kemudian diikuti dengan penerapan Paket A dan Paket B. Sedangkan tanaman terendah $(97,1 \mathrm{~cm})$ juga terlihat dengan Paket Petani (Tabel 4). Mandal et al. (2003) dan Cho et al. (2002) melaporkan bahwa pertumbuhan tanaman seperti; perkembangan akar, pertumbuhan tinggi tanaman, pembentukan anakan, percepatan pembungaan, dan ketahanan tanaman terhadap hama dan penyakit sangat tergantung pada ketersediaan dan kecukupan hara nitrogen $(\mathrm{N})$ phosfat $(\mathrm{P})$ dan kalium (K). Namun demikian, penggunaan pupuk anorganik saja secara terus menerus yang semakin meningkat menyebabkan ketidakseimbangan hara dalam tanah, bahkan dapat menimbulkan masalah sosial, ekonomi, meningkatnya biaya produksi, menurunnya kualitas hasil pertanian, dan menurunnya kualitas lingkungan akibat polusi air, tanah, dan udara telah banyak dilaporkan oleh peneliti sebelumnya (Clark et al. 1998; Phomassack et al. 2003; Kish dan Martin 2006; Wood et al. 2006). Selanjutnya Adiningsih et al. (1989) melaporkan bahwa penggunaan pupuk N, P dan K yang cukup harus sesuai dengan kebutuhan tanaman dan keseimbangan hara dalam tanah. Oleh karena itu harus diikuti dengan pemberian bahan organik sehingga meningkatkan produktivitas dan kualitas lingkungan produksi. Oleh karena itu, penggunaan pupuk organik menjadi sangat penting untuk memperbaiki kualitas tanah, produktivitas lahan sawah dan kualitas hasil (Landa et al. 1992; Clark et al. 1998; Whitbread et al. 2000; Mandal et al. 2003; dan Xu et al. 2006).

\section{Komponen Hasil Padi Sawah}

Keragaan komponen hasil padi sawah varietas Inpari 21 Batipuh dengan beberapa perlakuan PHSL dapat di lihat pada Tabel 5. Data rata-rata hasil pengamatan komponen hasil dari paket perlakuan PHSL yang diuji menunjukkan bahwa komponen hasil jumlah malai terbanyak (314 malai. $\mathrm{m}^{-2}$ ) didapatkan dengan penerapan Paket B, tetapi tidak berbeda dengan jumlah malai yang didapatkan dengan penerapan Paket A atau dengan Paket C. Sedangkan jumlah malai yang paling sedikit (245 malai. $\mathrm{m}^{-2}$ ) terlihat dengan penerapan Paket Petani. Jumlah gabah per malai dengan penerapan Paket $\mathrm{A}$ atau Paket $\mathrm{B}$, atau Paket $\mathrm{C}$ tidak berbeda nyata, tetapi jumlah gabah per malai terbanyak (113,1 gabah/malai) didapat dengan penerapan Paket C, kemudian dikuti oleh Paket B, dan 


\section{Jurnal Pertanian Terapan}

Paket A. Sedangkan Paket Petani memberikan jumlah gabah per malai yang sedikit (106,3 gabah/malai). Keadaan yang relatif sama juga terlihat dari rata- rata hasil pengamatan persentase gabah bernas, dimana juga tidak terlihat perbedaan yang nyata antar ketiga Paket PHSL yang di uji, masing-masing dengan persentase gabah bernas sebagai berikut; 85,7\% dengan Paket A, 89,1\% dengan paket B, dan 85,5\% dengan penerapan Paket C. Perlakuan PHSL yang diuji tidak nyata pengaruhnya terhadap bobot 1.000 biji varietas padi Inpari 21 Batipuh, dimana bobot 1.000 biji berkisar 28,43 g-29,05 g (Tabel 5).

Tabel 5. Pengaruh perlakuan pengelolaan hara spesifik lokasi (PHSL) terhadap Komponen hasil padi sawah pada lahan berpotensi hasil rendah di Kasang, Kecamatan Batang Anai Kabupaten Padang Pariaman MT. 2013

\begin{tabular}{|c|c|c|c|c|}
\hline $\begin{array}{l}\text { Perlakuan*) } \\
\text { PHSL }\end{array}$ & $\begin{array}{l}\text { Jumlah Malai } \\
\left(\text { malai.m }^{-2}\right)\end{array}$ & $\begin{array}{c}\text { Jml Gabah } \\
\text { Per malai } \\
\text { (gabah/malai }\end{array}$ & $\begin{array}{c}\text { Persentase } \\
\text { gabah bernas } \\
(\%)\end{array}$ & $\begin{array}{c}\text { Berat } 1.000 \text { biji } \\
(\mathrm{g})\end{array}$ \\
\hline Paket A & $291 \mathrm{a}$ & $109,2 \mathrm{ab}$ & $85,7 \mathrm{ab}$ & $29,05 \mathrm{a}$ \\
\hline Paket B & $314 \mathrm{a}$ & $112,8 \mathrm{a}$ & $89,1 \mathrm{a}$ & $28,90 \mathrm{a}$ \\
\hline Paket C & $296 \mathrm{a}$ & $113,1 \mathrm{a}$ & $85,5 \mathrm{ab}$ & $28,99 \mathrm{a}$ \\
\hline Paket Petani & $245 \mathrm{~b}$ & $106,3 \mathrm{~b}$ & $82,3 \mathrm{~b}$ & $28,43 \mathrm{a}$ \\
\hline
\end{tabular}

Angka selajur yang diikuti oleh huruf kecil yang sama tidak berbeda nyata menurut DNMRT 5\%*).

Dilaporkan bahwa kombinasi antara pupuk NPK dengan pupuk organik nyata mencegah terjadinya kemunduran kualitas tanah (Xu et al. 2006). Hasil yang sama juga didapatkan oleh Sukristiyonubowo et al. (1993) bahwa kombinasi pemberian pupuk NPK dengan bahan organik mampu memperbaiki sifat kimia tanah, yaitu memperbaiki pH, kadar bahan organik dan KTK tanah. Selanjutnya akan berpengaruh positif terhadap keragaan pertumbuhan tanaman yang ditunjukkan dengan keragaan komponen hasil dan hasil, dimana kombinasi pupuk NPK dan kompos jerami padi meningkatkan keragaan komponen hasil dan hasil gabah kering padi varietas IR64 (Sukristiyonubowo dan Tuherkih 2009).

\section{Hasil Gabah Kering Giling}

Perlakuan pengelolaan hara spesifik lokasi (PHSL) nyata meningkatkan hasil padi sawah varietas Inpari 21 Batipuh di lokasi pengkajian lahan sawah bepotensi rendah yaitu di Kasang, Kabupaten Padang Pariaman (Tabel 6).

Tabel 6. Pengaruh perlakuan pengelolaan hara spesifik lokasi (PHSL) terhadap hasil dan indeks hasil padi sawah pada lahan berpotensi hasil rendah di Kasang, Kecamatan Batang Anai, Kab. Padang Pariaman MT. 2013

\begin{tabular}{lcc}
\hline \multicolumn{1}{c}{ Perlakuan PHSL*) } & $\begin{array}{c}\text { Hasil Gabah Kering }(\mathrm{GKG}) \\
(\mathrm{t} / \mathrm{ha})\end{array}$ & $\begin{array}{c}\text { Perbedaan hasil } \\
\text { dengan Paket Petani } \\
(\%)\end{array}$ \\
\hline Paket A & $5,92 \mathrm{~b}$ & 24,9 \\
Paket B & $6,36 \mathrm{a}$ & 34,2 \\
Paket C & $6,14 \mathrm{ab}$ & 29,5 \\
Paket Petani & $4,74 \mathrm{c}$ & - \\
\hline
\end{tabular}

Angka selajur yang diikuti oleh huruf kecil yang sama tidak berbeda nyata menurut DNMRT 5\%*) 
Data rata-rata hasil gabah kering giling di Kasang menunjukkan bahwa perlakuan PHSL Paket B memberikan hasil gabah kering giling (GKG) tertinggi (6,36 t/ha). Perlakuan Paket B ini meningkatkan hasil sebesar 34,2\% dibanding dengan Paket petani, kemudian diikuti dengan hasil yang dicapai dengan penerapan Paket $\mathrm{C}$ yang memberikan hasil sebanyak 6,14 t/ha, dengan peningkatan hasil sebesar 29,5\%. Sedangkan penerapan Paket A memberikan hasil sebanyak 5,92 t/ha yang juga meningkatkan hasil sebesar 24,9\% dibanding dengan penerapan Paket Petani. Hasil penelitian Widowati dan Rochayati (2008) menyimpulkan bahwa penambahan N,P, K bersama dengan bahan organik dapat meningkatkan produktivitas lahan. Lebih lanjut, Sukristiyonubowo et al. (2009a) juga melaporkan bahwa pemupukan dengan takaran $250 \mathrm{~kg} / \mathrm{ha}$ urea, $200 \mathrm{~kg} / \mathrm{ha} \mathrm{SP} 18$ dan $100 \mathrm{~kg} / \mathrm{ha} \mathrm{KCl}$ yang dikombinasikan dengan 2 tha pukan dan 2 t/ha kompos jerami pada lahan sawah nyata meningkatkan hasil padi sawah IR42.

\section{KESIMPULAN}

1. Perlakuan pengelolaan hara spesifik lokasi (PHSL) nyata mempengaruhi pertumbuhan tanaman (jumlah anakan dan tinggi tanaman), Anakan terbanyak didapatkan dengan Perlakuan PHSL Paket B. Beberapa komponen hasil padi sawah varietas Inpari 21 Batipuah juga nyata dipengaruhi oleh PHSL. Perlakuan PHSL Paket A, B dan C nyata meningkatkan jumlah malai. Jumlah gabah per malai meningkat nyata dengan perlakuan Paket B dan Paket C. sedangkan persentase gabah bernas hanya meningkat nyata dengan Paket $\mathrm{B}$.

2. Perlakuan PHSL Paket A, Paket B maupun paket $\mathrm{C}$ nyata meningkatkan hasil gabah kering giling (GKG), masing-masing meningkatkan hasil 24,9\%; 34,2\% dan 29,5\% dibanding dengan Paket Petani pada lahan berpotensi hasil rendah. Rendahnya hasil dengan perlakuan Paket Petani disebabkan oleh tidak mencukupinya kebutuhan hara untuk pertumbuhan tanaman dan pengelolaan hara yang kurang tepat.

\section{SARAN}

Aplikasi pupuk anorganik sebaiknya diikuti dengan aplikasi bahan/pupuk organik, baik dalam bentuk pupuk kandang, maupun kompos jerami. Aplikasi pupuk kandang atau kompos harus dari pupuk kandang atau kompos yang telah matang.

\section{UCAPAN TERIMA KASIH}

Penulis mengucapkan Terima kasih kepada Saudara Taufik (Teknisi BPTP Sumbar) dan Susviyanti (Penyuluh Batang Anai) dan juga kepada Bapak Wali Akhir (Ketua Kelompok Tani Saiyo Sakato) yang telah membantu dalam pelaksanaan kegiatan dan pengamatan di lapangan.

\section{DAFTAR PUSTAKA}

Adiningsih, J. 1992. Peranan efisiensi penggunaan pupuk untuk melestarikan swasembada pangan. Orasi pengukuhan Ahli Peneliti Utama. Badan Penelitian dan Pengembangan Pertanian. Jakarta 45 hal.

Adiningsih, J., S.Moersidi., M. Sudjadi, dan A.M. Fagi 1989. Evaluasi keperluan fospat pada lahan sawah intensifikasi di Jawa. Dalam: Prosiding Lokakarya Nasional Efisiensi Penggunaan Pupuk. 


\section{Jurnal Pertanian Terapan}

Abdurachman, A., Irsal las, A. Hidayat, dan E. Pasandaran, 2001. Optimalisasi sumberdaya lahan dan air untuk pembangunan pertanian tanaman pangan. Dalam. A. Makarim.K (Eds). Tonggak Kemajuan Teknologi Produksi Pangan. Puslitbangtan, Badan Litbang Pertanian, p.28-44.

Anonim. 2005. Teknologi sawah bukaan baru areal irigasi Batang Hari. http://www.bbp2tp.litbang.deptan.go.id.

Balai Penelitian Tanah. 2009. Petunjuk Teknis Analisis KimiaTanah, Tanaman, Air dan Pupuk. Edisi 2. Balai Penelitian Tanah.Bogor. 211 hal.

Badan Pusat Statistik (BPS) Provinsi Sumatera Barat, 2012. Sumatera Barat Dalam Angka. Tahun 2011.

Cho, J.Y.,K.W.Han,J.K.Choi,Y.J.Kimand, and K.S.Yoon. 2002. N and P losses from paddy field plot in Central Korea. Soil Science and Plant Nutrition.48: 301-306.

Clark, M.S.,W.R.Horwath,C.Shennandan, and K.M. Scow. 1998. Changes in soil chemical properties resulting from organic and low-input farming practices. Agronomy Journal. 90:662-671p.

Dinas Pertanian Tanaman Pangan (Diperta) Provinsi Sumatera Barat, 2012. Keragaan produktivitas padi sawah per kecamatan di Sumatera Barat.

Kish, S. dan J. Martin. 2006. Organic and integrated farming key to lowering nitrogen leaching. CSREES Reseach Results.

Landa, J.K., R.P.Pareek, dan M. Becker. 1992 . Stem nodulating Rhyzobium symbiosis and its agronomic use in lowland rice. Advanced Soil Science.20p.

Mandal, K. Uttam, G. Singh, U.S.Victor, and K.L. Sharma,2003. Green manuring: It is effect on soil properties and crop growth under rice-wheat cropping system. European Journal of Agronomy. 19:225-237.

Phommassack,T.,A.Chanthavongsa,C.Sihavong, C.Thonglatsamy, C.Valentine, A.De Rouw,P. Marchand, dan V.Chaplot. 2003. An innovative approach to sustainable land management in Lao PDR.MSEC-Lao PDR Annual Report, In: Wani,S.P.,A.. Maglinoa, A. Ramakrisna, and T.J.Rego.Eds. Integrated catchment management for land and water conservation and sustainable agricultural production in Asia.CD-Rome.

Purwanto.S. 2008. Implementasi kebijakan untuk pencapaian P2BN). Dalam. B. Suprihatno et al. (Eds). Hasil-Penelitian Padi Menunjang P2BN. Prosid. Seminar Apresiasi (Buku I), Balai Besar Penelitian Tanaman Padi, Badan Litbang Pertanian. p.9-37.

Sukristiyonubowo, Mulyadi,P. Wigena, dan Kasno. A. 1993. Pengaruh pemberian bahan organic, kapur dan pupuk NPK terhadap sifat tanah dan hasil kacang tanah. Journal Tanah dan Pupuk. Pusat Penelitian Tanah dan Agroklimat. No.11:1-7.

Sukristiyonubowo. 2007. Nutrient balances in terraced paddy fields under traditional irrigation in Indonesia. PhD thesis. Faculty of Bioscience Engineering, Ghent University, Ghent Belgium, $184 \mathrm{p}$.

Sukristiyonubowo. Dan E. Tuherkih. 2009. Rice production in terraced paddy field systems. Journal Penelitian Pertanian Tanaman Pangan. 28 (3): 139-147. 
Sukristiyonubowo, I.G. Putu Wigena, R. Ladiyani, E.A. Kosman, dan H. Lutful. 2009a. Laporan akhir pengembangan teknologi pemupukan dan pengolahan tanah untuk meningkatkan produktivitas sawah bukaan baru di atas 30\%. Kerjasama Penelitian antara Badan Penelitian dan Pengembangan Pertanian dengan Direktorat Perguruan Tinggi melalui program SINTA.

Sukristiyonubowo, Ladiyani R., E.A. Kosman, dan Suwandi. 2009b. Pengaruh pengelolaan hara terhadap sifat tanah dan hasil padi varietas IR42 pada sawah bukaan baru. Paper disajikan pada Seminar Nasional Balai Besar Sumber Daya Lahan Pertanian, 24-25 November 2008.

Whitebread,M.A.Blair,J. Graeme, dan R.D.B. Lefroy. 2000. Managing legume leys, residues and fertilizers to enhance the sustainability of wheat cropping system in Australia.I. The effects on wheat yields and nutrient balance. Soil and Tillage Research. 54: 63-75.

Widowati, L.N, dan S. Rochayati. 2008. Pengelolaan hara untuk meningkatkan produktivitas lahan sawah bukaan baru di Harapan Masa-Tapin Kalimantan Selatan. Makalah disajikan pada Seminar Nasional BB-SDLP, 25-27 November 2008.13p

Wood,R., M. Lensen, C.dey, dan S. Lundie. 2006. A comparative study of some environmental impacts of conventional and organic farming in Australia. Agricultural Systems 89: 324-348.

Xu, Y., F. Zhang, X. Ho, J. Wang,R. Wang, dan X. Kong. 2006. Influence of management practices on soil organic matter changes in the Northern China Plain and Northeast China. Soil and Tillage Research. 86: 230-236. 